\title{
Molecular Characterization and Detection of 16SrIII Group Phytoplasma Associated with Huanglongbing Symptoms
}

\author{
Nelson Arno Wulff, $1, \dagger$ Camila Giacomo Fassini,2 Viviani Vieira Marques, ${ }^{2}$ Elaine Cristina Martins, ${ }^{2}$ \\ Daniela Aparecida Bononi Coletti, ${ }^{2}$ Diva do Carmo Teixeira, ${ }^{2}$ Marcio Martinello Sanches, ${ }^{3}$ and Joseph Marie Bové2,4
}

${ }^{1}$ Departamento de Pesquisa \& Desenvolvimento, Fundecitrus, Araraquara, SP, 14807-040 and PPG Biotecnologia, IQ/UNESP Araraquara, SP, 14800-060. Brazil; ${ }^{2}$ Departamento de Pesquisa \& Desenvolvimento, Fundecitrus, Araraquara, SP, 14807-040, Brazil; ${ }^{3}$ Embrapa Recursos Genéticos e Biotecnologia, Brasília, DF, 70770-917, Brazil; and ${ }^{4}$ UMR 1332 Biologie du Fruit et Pathologie, Université de Bordeaux, INRA, 71 avenue Edouard Bourlaux, CS20032, F-33882 Villenave d'Ornon Cedex, France Accepted for publication 16 September 2018.

\begin{abstract}
When huanglongbing (HLB) was found in Brazil in 2004, 'Candidatus Liberibacter americanus' was infecting most of the trees while ' $\mathrm{Ca}$. L. asiaticus' was present in a minor proportion. Currently, 'Ca. L. asiaticus' is the predominant bacterium associated with HLB in citrus trees in São Paulo (SP) and Minas Gerais (MG) States, the major citrus-growing regions in Brazil. A phytoplasma from the 16 SrIX group was associated with HLB symptoms in Brazil in 2007, in plants free of Liberibacter spp. In this report, HLB samples testing negative for ' $\mathrm{Ca}$. L. asiaticus', ' $\mathrm{Ca}$. L. americanus', and 16SrIX phytoplasma were infected with 16SrIII phytoplasmas. Coinfection with ' $\mathrm{Ca}$. L. asiaticus' and 16SrIII was also found. The $16 \mathrm{~S}$ ribosomal RNA (rRNA) gene sequences from 22 samples were obtained and sequenced, confirming that the 16SrIII group phytoplasma is associated with HLB symptoms in SP and MG States. Ten

single-nucleotide polymorphisms (SNPs) were found in the 1,427-bp 16S rRNA gene sequences from 16SrIII phytoplasmas from citrus, whereas none was detected in $16 \mathrm{~S}$ rRNA gene sequences among $16 \mathrm{SrIX}$ phytoplasma from citrus. Ribosomal protein (rp) rpsSrplVrpsC gene sequences were amplified with $16 \mathrm{SrIII}$ group-specific primers, sequenced from a subset of nine samples, and assembled into three groups based on eight SNPs. SNPs in 16S rRNA gene and rp gene sequences are common in 16SrIII phytoplasmas from other hosts and this phytoplasma group is widespread in South America. 16SrIII phytoplasmas highly related are commonly found in Melia azedarach, a widespread tree in Brazil and Argentina. The finding of a new phytoplasma associated with HLB symptoms belonging to the $16 \mathrm{SrIII}$ group reinforces the need to develop diagnostic tools to assess HLB-associated microbiomes.
\end{abstract}

'Candidatus Liberibacter asiaticus' is associated with huanglongbing (HLB) in China, Brazil, and the United States, the three greatest citrus producers (FAO 2016). In Brazil, ' $\mathrm{Ca}$. L. americanus' has been reported infecting citrus trees (Teixeira et al. 2005) and orange jasmine (Lopes et al. 2010) and, despite its presence, ' $\mathrm{Ca}$. L. asiaticus' is the predominant species associated with HLB (Lopes et al. 2009) (N. A. Wulff, unpublished results). ' $C a$. L. asiaticus' is of worldwide importance, occurring in Asia, the Americas, the Middle East, and Ethiopia (Bové, 2006; Saponari et al. 2010), vectored by Diaphorina citri (Capoor et al. 1967). 'Ca. L. africanus', also associated with HLB, occurs in Africa (Pietersen et al. 2010), Mauritius and Reunion Islands (Garnier et al. 1996), and Yemen (Bové and Garnier 1984). In Africa, a striking diversity of 'Ca. L. africanus' subspecies is reported (Roberts et al. 2017).

The most conspicuous symptom of HLB is the presence of blotchy mottle in leaves and the occurrence of lopsided fruit with

${ }^{\dagger}$ Corresponding author: Nelson Arno Wulff;

E-mail: nelson.wulff@fundecitrus.com.br

Funding: N. A. Wulff received a Conselho Nacional de Desenvolvimento Científico e Tecnológico fellowship (308997/2014-0). Partial financial support was provided by Fundação de Amparo à Pesquisa do Estado de São Paulo (2007/ 55013-9) and by Embrapa.

Note: This report is dedicated to Prof. Joseph Marie Bové. With his enthusiasm, leadership, and knowledge, he actively contributed to HLB research worldwide and helped Fundecitrus spread lessons on disease management. Dr. Bové died 2 July 2016 , before the final version of this manuscript was ready.

*The $\boldsymbol{e}$-Xtra logo stands for "electronic extra" and indicates that one supplementary figure is published online.

(C) 2019 The American Phytopathological Society aborted seed and, eventually, showing color inversion (Bové 2006). HLB is spreading in America and management practices include planting young healthy trees; inspection; and removal of affected, symptomatic trees coupled with psyllid insecticide treatment (Bassanezi et al. 2013; Belasque et al. 2010; Miranda et al. 2018). To achieve such efforts, scouting teams need to be trained in the recognition of symptoms, and diagnostic tests are used for confirmatory purposes. Doubtful symptoms may hinder proper HLB diagnosis, and standard diagnostic techniques are also used to solve such doubts. The diagnostic of HLB-associated bacteria has been carried out mainly by polymerase chain reaction (PCR) $(\mathrm{Li}$ et al. 2006; Teixeira et al. 2005, 2008a; Wang et al. 2006), although isothermal amplification has been described as well (Li et al. 2007).

' $\mathrm{Ca}$. Liberibacter' spp. found in citrus are associated with HLB and, despite lacking conceptual proof of Koch's postulates, the overwhelming amount of data support the concept of Liberibacters as the etiological agent of HLB, including detection surveys (Pietersen et al. 2010; Teixeira et al. 2005) and metagenomic information (Duan et al. 2009; Lin et al. 2015; Tyler et al. 2009; Wulff et al. 2014). In addition to ' $C a$. Liberibacter' spp., Spiroplasma citri (Saglio et al. 1973) and ' $\mathrm{Ca}$. Phytoplasma aurantifolia' in citrus (Zreik et al. 1995) cause diseases distinct from HLB. Among phytoplasmas, ' $\mathrm{Ca}$. P. aurantifolia' (16SrII) was the first associated with a citrus disease, witches'-broom disease of lime (Zreik et al. 1995). A 16SrIX phytoplasma was found infecting sweet orange trees in Brazil in the states of São Paulo in 2007 (Teixeira et al. 2008b), Minas Gerais in 2008, Bahia in 2012 (Wulff et al. 2015), and Federal District in 2016 (Sanches et al. 2016), while 16 SrIII was first reported in 2010, without nucleotide sequence characterization (Barbosa 2010). Low levels of incidence were reported for these phytoplasmas when compared with ' $\mathrm{Ca}$. L. asiaticus' prevalence in Brazil. Trees infected with 16SrIX 
phytoplasma have foliar and fruit symptoms indistinguishable from those caused by ' $\mathrm{Ca}$. Liberibacter' spp. Sun Hemp plants, especially those harboring witches'-broom symptoms, act as a reservoir of the HLB-associated 16SrIX phytoplasma (Wulff et al. 2015). In China, 'Ca. P. asteris' (16SrI) was associated with HLB in 2009 (Chen et al. 2009), while a subgroup 16SrII-A phytoplasma was reported in HLB-like affected grapefruit in 2010 (Lou et al. 2014). Phytoplasmas from subgroup 16SrII-C were detected in sweet orange, lime, and sweet lime in Iran (Alizadeh et al. 2017; Saberi et al. 2017). The 16SrII-A phytoplasma is from a distinct subgroup associated with witches'-broom disease of lime, which belongs to subgroup16SrIIB (Zreik et al. 1995). Phytoplasmas of group 16SrI (Arratia-Castro et al. 2014; Poghosyan et al. 2015) and group 16SrIX (Sanches et al. 2016; Wulff et al. 2015) were found in Mexico, while phytoplasma from group 16SrVI was found in mandarin in India in coinfection with ' $\mathrm{Ca}$. L. asiaticus' (Das et al. 2016). 16SrIX and 16SrI phytoplasmas have symptoms indistinguishable from those observed in HLB associated with ' $C a$. Liberibacter' spp. (Chen et al. 2009; Teixeira et al. 2008b).

As part of the diagnostic service of HLB provided by Fundecitrus to growers, 'Ca. L. asiaticus', 'Ca. L. americanus', and 16SrIX phytoplasma are tested in citrus leaf samples by quantitative PCR (qPCR) procedures. Similar to what occurred in 2007 (Teixeira et al. 2008 b), a phytoplasma was found infecting sweet orange trees that tested negative to Liberibacter (' $\mathrm{Ca}$. L. americanus' and ' $\mathrm{Ca}$. L. asiaticus') but also tested negative to 16 SrIX phytoplasma. Samples had blotchy mottle in most of the cases but yellow vein discoloration and chlorosis were also present. Because none of the previously known HLB-associated bacteria were detected, a search for phytoplasmas was carried out. Molecular characterization of these samples with PCR techniques to detect phytoplasmas, and amplicon sequencing as well, revealed the occurrence of 16SrIII phytoplasmas. A new phytoplasma associated with HLB was characterized in two loci, 16S ribosomal RNA (rRNA) gene and ribosomal protein (rp) gene sequences, from sweet orange samples. The detection, characterization, and distribution of this 16 SrIII phytoplasma is discussed.

\section{MATERIALS AND METHODS}

Plant material and DNA extraction. Sweet orange (Citrus sinensis Osbeck) leaf samples were selected from the Citrus Disease and Pest Diagnostic Center service (Fundecitrus Diagnostic Laboratory) or collected in citrus orchards. Samples showing blotchy mottle leaves that tested negative to ' $\mathrm{Ca}$. L. asiaticus', ' $\mathrm{Ca}$. L. americanus', and 16SrIX phytoplasma were further investigated for the presence of phytoplasmas. After $16 \mathrm{SrIII}$ phytoplasmas were found, additional symptomatic samples, either positive for ' $\mathrm{Ca}$. $\mathrm{L}$. asiaticus' and 16SrIX phytoplasma or free of the ' $\mathrm{Ca}$. L. asiaticus', ' $C a$. L. americanus', and 16SrIX phytoplasma were used to search for coinfection with $16 \mathrm{SrIII}$ phytoplasma. Also, asymptomatic samples, free of ' $C a$. L. asiaticus', ' $C a$. L. americanus', and 16SrIX phytoplasma, were used to search for 16 SrIII phytoplasma.

Leaflet samples from Melia azedarach, known as cinamomo or Chinaberry tree, showing little leaf symptoms were selected; a leaf blade was removed and used for DNA extraction. Periwinkle harboring virescence, typical symptom of phytoplasma infection was collected in a garden.

For DNA extraction, $0.5 \mathrm{~g}$ of leaf midribs and petioles from each sample was sliced and ground in cetyltrimethylammonium bromide (CTAB) buffer with $\beta$-mercaptoethanol according to the CTAB protocol (Teixeira et al. 2008a). DNA quality and concentration were assessed with NanoDrop (Thermo Scientific, Waltham, MA, USA).

Detection of group IX phytoplasma, ' $\mathrm{Ca}$. L. asiaticus', and ' $\mathrm{Ca}$. L. americanus' associated with HLB in Brazil. In total, 226 samples were assessed for phytoplasma infection by PCR, as detailed below. Detection of ' $\mathrm{Ca}$. L. asiaticus', ' $\mathrm{Ca}$. L. americanus'
(Li et al. 2006), and group IX phytoplasma (Wulff et al. 2015) was done by qPCR. Plant DNA detection was done as described (Li et al. 2006). A lot of 69 citrus samples was assessed only by conventional PCR tests to detect phytoplasmas.

PCR amplification of bacterial 16S rRNA gene in citrus leaves. Detection of 16S rRNA gene was performed essentially as described by Teixeira et al. (2005) with primers fD1 and rP1 (Weisburg et al. 1991).

Detection of phytoplasma by nested PCR amplification of $16 \mathrm{~S}$ rRNA genes with universal primers and sequencing of the amplicons for group identification. Phytoplasma detection was carried out by PCR with the universal primers P1/P7 (Deng and Hiruki 1991; Schneider et al. 1995) which amplify the $16 \mathrm{~S}$ rRNA gene from phytoplasmas in general. To increase sensitivity, the first round of PCR was diluted $50 \times$ and $1 \mu \mathrm{l}$ was used for nested amplification with primers R16mF2 and R16mR1 (Gundersen and Lee 1996), leading to an amplicon of approximately $1.4 \mathrm{kbp}$. The presence of $\mathrm{R} 16 \mathrm{mF} 2$ and $\mathrm{R} 16 \mathrm{mR} 1$ amplicons is indicative of a sample considered positive for the presence of phytoplasma. In the absence of a PCR product, the sample was considered negative. This PCR was carried out with 73 samples that tested negative in the qPCR for ' $C a$. L. asiaticus', ' $C a$. L. americanus', and 16SrIX phytoplasma and 1 sample that was positive for 16SrIX phytoplasma.

For the identification of the phytoplasma $16 \mathrm{Sr}$ group present in the positive samples, the nested PCR amplicon products were purified (Kit Wizard SV Gel and PCR Clean-UP System; Promega Corp., Madison, WI, USA) and sequenced with chain-terminating dideoxynucleosides at Macrogen (Seoul, South Korea). Sequenced reads were obtained with amplification primers $\mathrm{R} 16 \mathrm{mF} 2 / \mathrm{R} 16 \mathrm{mR} 1$ and with primers annealing internally to the R16mF2/R16mR1 binding sites: fU5 and rU3 (Seemüller et al. 1994), primers 518F (CCAGCAGCCGCGGTAATACG) and 800R (TACCAGGG TATCTAATCC) (universal primers for $16 \mathrm{~S}$ rRNA gene sequencing from Macrogen), and two additional internal primers designed on the basis of the consensus sequences obtained from the positive samples Pint_fw_III (ATCAGGAAAACAGGTGGTGC) and Pint_rv_III (AGCACAACAGCGTTAAGCAC) (this work).

Sequence reads were analyzed using the software CodonCodeAligner (version 8.0.1; CodonCode Corporation, Certerville, MA), automatically clipped at ends, checked manually for quality, and assembled into contigs. Consensus sequences were manually curated and quality cut-off of 20 was used to edit the consensus. Sequenced regions where single-nucleotide polymorphisms (SNPs) between samples were found had at least with two independent PCR reads sequences. Nucleotide sequence analysis was carefully curated especially at annotated SNPs detected among samples. The final contig consensus for each sample was aligned using the same software. Similarity searches for the consensus sequences from each sample were conducted with Blastn (https://blast.ncbi. nlm.nih.gov/Blast.cgi) and $i$ PhyClassifier (Zhao et al. 2009).

Among the 16SrIX phytoplasma samples detected at the diagnostic service (Wulff et al. 2015), five citrus samples from São Paulo State municipalities (Colombia, Getulina, Onda Verde, Paranapua, and Sud Mennucci) and five samples from Matias Cardoso municipality from Minas Gerais State had the 16S rRNA gene PCR amplified (P1/P7 and R16mF2/R16mR1), sequenced, and analyzed as indicated above.

Detection and characterization of group 16SrIII phytoplasma by PCR amplification of rp genes rpsSrplVrpsC and amplicon sequencing. Specific group 16SrIII PCR amplification was achieved with primers described in the literature. DNA samples were amplified with $0.5 \mu \mathrm{M}$ primers $\mathrm{rpL} 2 \mathrm{~F} 3$ and $\mathrm{rp}(\mathrm{I})$ R1A (Martini et al. 2007) and 1 U of Phusion high-fidelity DNA polymerase (Thermo Scientific) in a final volume of $40 \mu \mathrm{l}$. Cycling conditions consisted of one step at $98^{\circ} \mathrm{C}$ for $30 \mathrm{~s}$; followed by 35 cycles of $98^{\circ} \mathrm{C} 20 \mathrm{~s}, 40^{\circ} \mathrm{C}$ for $30 \mathrm{~s}$, and $72^{\circ} \mathrm{C}$ for $75 \mathrm{~s}$; with a final extension step of $5 \mathrm{~min}$. For nested PCR, the first reaction was 
diluted $25 \times$ and $2 \mu \mathrm{l}$ was employed in PCRs with primers $\mathrm{rp}$ (III)-FN (Davis et al. 2013) and rp(III)R1 (Martini et al. 2007) in the case of sweet orange and Chinaberry tree, and primers rp(III)-FN/rp(I)R1A with periwinkle template DNA (Davis et al. 2013; Martini et al. 2007). PCR conditions were as mentioned above and cycling parameters consisted of one stage at $98^{\circ} \mathrm{C}$ for $30 \mathrm{~s} ; 35$ cycles of $98^{\circ} \mathrm{C}$ $20 \mathrm{~s}, 49^{\circ} \mathrm{C}$ for $30 \mathrm{~s}$, and $72^{\circ} \mathrm{C}$ for $60 \mathrm{~s}$; followed by a final extension step of $5 \mathrm{~min}$. Samples that produced an amplicon of the expected size (close to $1.3 \mathrm{kbp}$ ) in agarose gel electrophoresis were considered positive. Negative and positive samples containing DNA from healthy trees and phytoplasma of 16SrIII and 16SrIX groups were included as controls, in addition to a nontemplate control. In total, 153 citrus samples with HLB symptoms were assessed by nested PCR to detect phytoplasmas with the abovedescribed protocol.

PCR products from selected samples were cleaned and sequenced with amplification primers [rp(III)-FN and $\mathrm{rp}(\mathrm{III}) \mathrm{R} 1]$, as well as internal primers designed on the basis of the amplified consensus obtained from this work: III_Fw1 (AGCGGATATTGATTATGCTT), III_Fw2 (CCGAAGATAAACAAGTTCCT), III_Rv1 (AGGAAC TTGTTTATCTTCGG), and III_Rv2 (GCTAAAATTATGAA CAGCGT). Sequence analysis was done as described above and similarity searches of consensus sequences with nucleotides sequences and translation products were conducted with Blastn and Blastp (https://blast.ncbi.nlm.nih.gov/Blast.cgi) and Clustal Omega (https://www.ebi.ac.uk/Tools/msa/clustalo/).

Cloning of rpsSrplVrps C amplicon. Nested PCR product from primers rp(III)-FN and rp(III)R1 of samples 70571 and 78049 were cloned into the blunt-end SmaI restriction site of $\mathrm{pBS}$ plasmid, sequenced, and analyzed as described above.

Phylogenetic analysis. 16S rRNA gene sequences and rp gene sequences of the sweet orange, periwinkle, and Chinaberry tree samples generated in this work and related phytoplasma strains from the 16SrIII group, citrus-associated phytoplasma, and representative
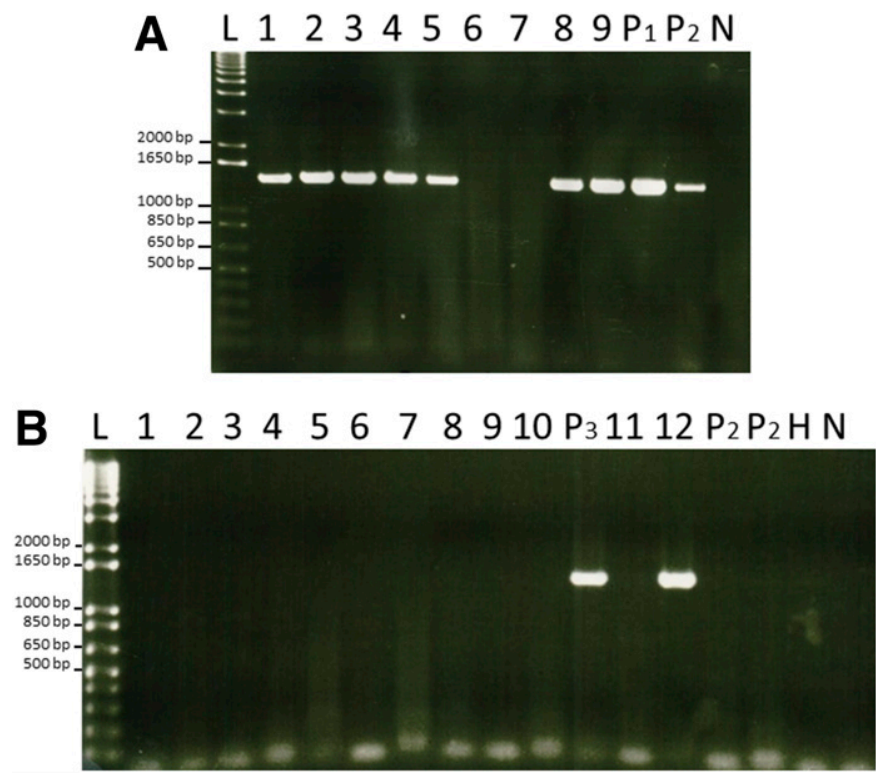

Fig. 1. Phytoplasma detection in sweet orange samples. A, Polymerase chain reaction (PCR) amplification of $16 \mathrm{~S}$ ribosomal DNA gene with primers P1/P7 followed by nested PCR primers R16mF2/R16mR1. Lanes 1 to $9=$ sweet orange DNA (positive samples 77297, 77315, 77317, 77520, 77524, 78044, and 78341); $\mathrm{P}_{1}=$ positive control DNA from Sunn Hemp 16SrIII phytoplasma; $\mathrm{P}_{2}=$ positive control DNA from sweet orange $16 \mathrm{SrIX}$ phytoplasma; and $\mathrm{N}=$ nontemplate control (NTC). B, PCR amplification of ribosomal protein genes with primers rpL2F3 and $\mathrm{rp}(\mathrm{I}) \mathrm{R} 1 \mathrm{~A}$, followed by nested PCR primers rp(III)FN and rp(III)R1, specific for 16SrIII phytoplasmas. Lanes 1 to $12=$ sweet orange DNA samples (positive sample 80456); $\mathrm{P}_{2}=$ positive control DNA from sweet orange 16SrIX phytoplasma; $\mathrm{P}_{3}=$ positive control DNA from Melia azedarach $16 \mathrm{SrIII}$ phytoplasma; $\mathrm{H}=$ DNA from healthy sweet orange; and $\mathrm{N}=\mathrm{NTC}$.
'Ca. Phytoplasma' spp. were obtained from the GenBank database. Phylogenetic and molecular evolutionary analysis were conducted using MEGA version 7.0.26 (Kumar et al. 2016).

\section{RESULTS}

Phytoplasma detection and $16 \mathrm{Sr}$ group assignment. Sweet orange leaves with blotchy mottle from the southwest of Minas Gerais State were tested for the presence of HLB-associated bacteria in Brazil and qPCR results failed to detect ' $C a$. L. asiaticus', ' $C a$. L. americanus', and 16SrIX group phytoplasma in such samples. Although the bacterial universal primers fD1 and rP1 failed to detect the 16S rRNA gene of bacteria in DNA from leaves (data not shown), nested PCR tests with universal phytoplasma primers (P1/P7 nested with $\mathrm{R} 16 \mathrm{mF} 2 / \mathrm{R} 16 \mathrm{mR} 1)$ did reveal the presence of phytoplasmas in several samples. The presence of phytoplasmas was assumed to be due to the presence of a 1.4-kbp amplicon (Fig. 1A). The sequence of amplicons from Figure 1A was obtained and Blastn analysis produced matches with 16SrIII group phytoplasmas, indicating the presence of a new phytoplasma associated with HLB symptoms.

Further evidence of 16SrIII phytoplasma to be associated with HLB symptoms. To understand the importance of the presence of 16SrIII phytoplasma in citrus, a set of 226 samples, including the 9 samples from Figure 1A, were then tested using qPCR for the occurrence of ' $\mathrm{Ca}$. L. asiaticus', ' $\mathrm{Ca}$. L. americanus', or the 16SrIX group phytoplasma, and by nested PCR techniques for the potential occurrence of phytoplasmas. Samples were selected according to the geographical regions, from São Paulo and Minas Gerais States, and by the presence of HLB symptoms. First, 73 samples were tested with nested universal phytoplasma primer PCR for the 16S rRNA gene; this group contained 1 sample infected with 16SrIX phytoplasma determined by qPCR specific for $16 \mathrm{SrIX}$ phytoplasmas (Wulff et al. 2015) and 17 samples infected with ' $C a$. L. asiaticus' as determined by qPCR (Li et al. 2006). The remaining 55 samples where negative for ' $C a$. L. asiaticus', ' $C a$. L. americanus', and 16SrIX phytoplasma. Out of 73 samples, 30 were positive for phytoplasmas, producing a 1.4-kbp amplicon in phytoplasma nested PCR, including 1 sample infected with 16SrIX phytoplasma and 1 sample that was ' $\mathrm{Ca}$. L. asiaticus' positive, being also phytoplasma positive. Second, a nested PCR specific for $\mathrm{rp}$ from 16SrIII group phytoplasmas was used to test 153 additional samples; this group contained 2 samples infected with $16 \mathrm{SrIX}$ phytoplasma as determined by qPCR specific for $16 \mathrm{SrIX}$ phytoplasmas (Wulff et al. 2015) and 22 samples infected with ' $C a$. L. asiaticus' as determined by qPCR (Li et al. 2006). The two samples with 16SrIX phytoplasma were negative in this nested rp group III PCR. Out of 22 samples infected with ' $\mathrm{Ca}$. L. asiaticus', 8 turned out to be also infected with 16 SrIII phytoplasma and 14 remained infected only with ' $\mathrm{Ca}$. L. asiaticus'. From the 129 samples negative for ' $C a$. L. asiaticus', 'Ca. L. americanus', and 16SrIX phytoplasma, 22 samples were PCR positive in the nested rp group III-specific PCR, producing a 1.3-kbp amplicon (Fig. 1B). The remaining 107 samples were negative for ' $\mathrm{Ca}$. L. asiaticus', ' $C a$. L. americanus', and phytoplasmas. The statistics for detection of ' $\mathrm{Ca}$. L. asiaticus', ' $\mathrm{Ca}$. L. americanus', and phytoplasmas from 16SrIX and 16SrIII groups are summarized in Table 1.

In addition, 36 samples were analyzed with nested PCR 16S rRNA universal phytoplasma primers, resulting in additional 11 positive samples for phytoplasmas, while 33 samples were analyzed with nested rp group III PCR, resulting in 5 positive samples for 16SrIII phytoplasmas.

A full-length amplicon 1,427 bp was sequenced from 22 samples that tested positive with the 16S rRNA gene nested PCR (Table 2), while the remained 16 samples were only partially sequenced with high-quality reads (838 to $1,426 \mathrm{bp}$ ). One sample had only short sequences of good quality and phytoplasma group identification was not possible. Seven sweet orange phytoplasma amplicons that 
were fully sequenced, two samples of periwinkle with virescence, and one sample of Chinaberry tree with little leaf also amplified a 16S rRNA gene in nested PCR product (Fig. 1A), producing a 1,427 bp sequence (Table 2). These sequences produced high hits with 16 SrIII phytoplasmas, the X-disease phytoplasma group.

Identification and relatedness to other phytoplasmas. The 22 sweet orange samples with fully sequenced 16 S rRNA genes had 9 distinct haplotypes (Table 3), due to 10 SNPs, without including samples with unresolved bases at positions 360 and 541. These sequences shared 99.1 to $99.4 \%$ similarity with $16 \mathrm{~S}$ rRNA gene sequence JQ044393 from ' $C a$. Phytoplasma pruni', the reference strain of Western X disease group/16SrIII group phytoplasmas(Davis et al. 2013). One of the samples with the 1,427-bp amplicon fully sequenced was coinfected with ' $\mathrm{Ca}$. L. asiaticus'.

TABLE 1. Detection of the 16SrIII group phytoplasma, 'Candidatus Liberibacter asiaticus', 'Ca. L. americanus', and 16SrIX group phytoplasma in 226 citrus samples

\begin{tabular}{lcc}
\hline $\begin{array}{l}\text { Huanglongbing (HLB)-associated } \\
\text { bacteria }^{\text {a }}\end{array}$ & $\begin{array}{c}\text { Number of } \\
\text { samples }\end{array}$ & Percentage \\
\hline 'Ca. L. asiaticus' & 30 & 13.3 \\
'Ca. L. americanus' & 0 & 0 \\
16SrIX group phytoplasma & 3 & 1.3 \\
16SrIII group phytoplasma & 50 & 22.1 \\
'Ca. L. asiaticus' + 16SrIII group & & \\
phytoplasma & 9 & 4.0 \\
No detection & 134 & 59.3 \\
\hline
\end{tabular}

a ' $C a$. L. asiaticus' and ' $C a$. L. americanus' were detected using a TaqMan protocol ( $\mathrm{Li}$ et al. 2006). 16SrIX group phytoplasma was detected using a TaqMan protocol (Wulff et al. 2015); 16SrIII group phytoplasma was detected with nested $16 \mathrm{~S}$ ribosomal RNA gene polymerase chain reaction (PCR) (29 samples) and nested ribosomal protein gene PCR (30 samples), while 11 samples infected with 16 SrIII phytoplasmas were detected by both techniques. No detection $=$ no HLB-associated bacteria were detected.
The virtual PCR-restriction fragment length polymorphism (RFLP) pattern (Zhao et al. 2009) of the 16S rRNA gene sequences from samples 68486, 70571, 70572, 74476, 76354, 76357, 76478, $77082,77315,77317,77524,77900,78001,78044$, and 78049 was identical to the reference pattern of subgroup $16 \mathrm{SrIII}-\mathrm{B}$, with a similarity coefficient of 1.00 to sequence AF189288, from the clover yellow edge phytoplasma. Sequences 77297 and 77520 were identical to the reference pattern of subgroup $16 \mathrm{SrIII}-\mathrm{X}$, with a similarity coefficient of 1.00 in relation to sequence KC412026, from Conyza bonariensis. The virtual PCR-RFLP pattern from samples 60378, 77892, 77963, 78017, and 78118 was different from the reference patterns of the 16SrIII subgroups, the most similar being subgroup III-B with sequence AF189288. With a similarity coefficient of 0.94 , lower than the threshold, these five sequences may represent a new subgroup within the 16 SrIII group. Sequences were uploaded to the National Center for Biotechnology Information (NCBI) (Table 2, accession numbers). The 14 samples with sequence reads smaller than $1,427 \mathrm{bp}$ ( 838 to $1,342 \mathrm{bp}$; data not shown) were confirmed to be 16 SrIII phytoplasma by Blastn and multiple alignment. Because these sequences were not complete, they were not deposited at NCBI. Overall, 37 samples were infected with group 16 SrIII phytoplasma as determined by nested PCR and sequencing.

The two periwinkle 16S rRNA gene sequences shared $99.3 \%$ similarity to JQ044393; however, they had a virtual PCR-RFLP pattern different from the reference patterns of all previously established $16 \mathrm{Sr}$ groups or subgroups, the most similar being the pattern of subgroup 16SrIII-B, with a similarity coefficient of 0.97 , which is equal to the threshold to establish a new subgroup. On the other hand, the 16S rRNA gene sequence of phytoplasma from Chinaberry tree sample N10202 was $99.4 \%$ similar to the reference strain JQ044393, with a similarity coefficient of 1.0 and belonging to subgroup 16SrIII-B (Zhao et al. 2009). The periwinkle and

TABLE 2. Plant samples used for the characterization of 16SrIII phytoplasmas based on the sequences of 16S ribosomal RNA (rRNA) gene and on the ribosomal protein (rp) gene rpsSrplVrpsC sequences

\begin{tabular}{|c|c|c|c|c|c|c|}
\hline Plant and origin ${ }^{\mathrm{a}}$ & Sample & 16S rRNA gene ${ }^{b}$ & Similarity ${ }^{\mathrm{c}}$ & Coefficient $^{\mathrm{d}}$ & 16SrIII subgroup ${ }^{\mathrm{e}}$ & $r p s \mathrm{~S} r p l \mathrm{~V} r p s \mathrm{C}^{\mathrm{b}}$ \\
\hline Sweet orange, MG & 60378 & MG744580 & 99.2 & 0.94 & $\mathrm{~B} /$ new subgroup & - \\
\hline Sweet orange, MG & 68486 & MG744581 & 99.2 & 1.00 & B & MG876747 \\
\hline Sweet orange, MG & 70571 & MG744582 & 99.2 & 1.00 & B & MG876748 \\
\hline Sweet orange, MG & 74476 & MG744583 & 99.3 & 1.00 & B & MG876749 \\
\hline Sweet orange, MG & 76354 & MG744584 & 99.3 & 1.00 & B & - \\
\hline Sweet orange, MG & 76357 & MG744585 & 99.3 & 1.00 & $\mathrm{~B}$ & MG876750 \\
\hline Sweet orange, MG & 76478 & MG744586 & 99.2 & 1.00 & B & MG876751 \\
\hline Sweet orange, MG & 77315 & MG744589 & 99.2 & 1.00 & $\mathrm{~B}$ & MG876752 \\
\hline Sweet orange, MG & 77317 & MG744590 & 99.2 & 1.00 & B & MG876753 \\
\hline Sweet orange, MG & 77520 & MG744591 & 99.2 & 1.00 & $\mathrm{X}$ & MG876754 \\
\hline Sweet orange, MG & 77524 & MG744592 & 99.3 & 1.00 & B & - \\
\hline Sweet orange, MG & 77892 & MG744593 & 99.2 & 0.94 & $\mathrm{~B} /$ new subgroup & - \\
\hline Sweet orange, MG & 77900 & MG744594 & 99.4 & 1.00 & B & - \\
\hline Sweet orange, MG & 77963 & MH016557 & 99.2 & 0.94 & $\mathrm{~B} /$ new subgroup & - \\
\hline Periwinkle, SP & N9574 & MG744578 & 99.3 & 0.97 & $\mathrm{~B} /$ new subgroup & - \\
\hline Periwinkle, SP & N9576 & MG744579 & 99.3 & 0.97 & $\mathrm{~B} /$ new subgroup & MG876746 \\
\hline Chinaberry tree, RS & N10202 & MG744577 & 99.4 & 1.00 & $\mathrm{~B}$ & MG876745 \\
\hline
\end{tabular}

a Common host names are indicated, as well as state of origin from the samples (Brazil); MG = Minas Gerais, SP = São Paulo, and RS = Rio Grande do Sul.

${ }^{b}$ Accession number deposited in GenBank from sequences obtained in this work; - indicates not sequenced.

c Percentage of similarity of the 16S rRNA gene sequence from the output of iPhyClassifier (Zhao et al. 2009) to 'Candidatus Phytoplasma pruni' rrnA reference strain (JQ044393).

d Similarity coefficient calculate by iPhyClassifier (Zhao et al. 2009) with the virtual restriction fragment length polymorphism (RFLP) pattern derived from 16S rRNA gene sequences delimited with primers R16F2n/R16R2. Sweet orange, periwinkle, and Chinaberry tree samples had RFLP patterns most similar to the sequence from clover yellow edge phytoplasma (AF189288), whereas sweet orange samples 77520 and 77297 were most similar to Conyza bonariensis phytoplasmas (KC412026).

e Subgroups were determined after percentage similarity and virtual RFLP pattern analysis using iPhyClassifier (Zhao et al. 2009). 
Chinaberry tree 16SrIII RNA gene sequences were different from the sweet orange 16SrIII RNA sequences.

The 16SrIII sequences were grouped according to their sequence similarity (Table 2) and further analyzed by Blastn. The 1,427-bp sequences of sweet orange were $99 \%$ identical, with $E$ value of 0.0 and $100 \%$ query coverage to several group $16 \mathrm{SrIII}$ phytoplasma DNA sequences. In the following description, samples connected by a dash share $100 \%$ sequence similarity between or among them. Phytoplasma 16S rRNA gene sequence from samples 60378/77892/77963/ $78017 / 78118$ (16SrIII-B/new subgroup) had the closest hits to KF941133 - a phytoplasma found in Sunn Hemp (Crotalaria juncea) in São Paulo State, Brazil (Wulff et al. 2015); AF495657-Chinaberry (Melia azedarach) yellows phytoplasma from Bolivia (Harrison et al. 2003); and KC412031-Solanum lycopersicum phytoplasma from Argentina (Galdeano et al. 2013). Sequences from sweet orange samples 70571, 70572/74476/77524, 76354/76357, 77315/77317, 77900/78001/78049, 78044 (subgroup 16SrIII-B), Chinaberry tree N10202, and sweet orange 77297/77520 (subgroup 16SrIII-X) had, as closest hits, Chinaberry yellows phytoplasma (AF495657), S. lycopersicum phytoplasma (KC412031), and GU292082-passion fruit witches'-broom phytoplasma from Brazil (Davis et al. 2012). Sequences from sweet orange 76478/68486 and $77082 \mathrm{had}$, as closest hits, the Chinaberry phytoplasma (AF495657) and S. lycopersicum phytoplasmas (KC412030 and KC412031) from Argentina (Galdeano et al. 2013), while the sequences from periwinkle were most closely related to Chinaberry phytoplasma (AF495657), Sunn Hemp phytoplasma (KF941133), and S. lycopersicum phytoplasma (KC412031). The 10 haplotypes from sweet orange and the sequences from Chinaberry tree and periwinkle were very similar to phytoplasmas found in hosts in South American countries.

Phylogenetic trees constructed with 16S rRNA gene sequences from isolates characterized here and from diverse group of phytoplasmas corroborate the identification of these phytoplasmas as group 16SrIII (Fig. 2A).

The rp characterization. The diversity observed in the 16SrIII phytoplasmas from sweet orange was further evaluated using the rp genes rpsSrplVrpsC. The amplicon from 17 samples was obtained with primers $\operatorname{rpL} 2 \mathrm{~F} 3$ and $\operatorname{rp}(\mathrm{I}) \mathrm{R} 1 \mathrm{~A}$ nested with primers $\mathrm{rp}(\mathrm{III})-\mathrm{FN}$ and $\mathrm{rp}(\mathrm{III}) \mathrm{R} 1$. Full amplicons from nine samples, 1,341 bp long, were sequenced. These nine samples also had the 16S rRNA gene sequenced (Table 2). Due to the presence of eight SNPs in these sequences, three sequence variants were identified (Table 3). When blasted with GenBank sequences (1 February 2018), the highest similarity of these sequences was with Catharanthus roseus phytoplasma (16SrIII-B, KC412022), Cucurbita maxima var. zapallito phytoplasma (16SrIII-J, KC412017), and Allium sativum phytoplasma (16SrIII-J, KC412014), from Argentina (Galdeano et al. 2013), with query coverage of $100 \%$ and e-value 0.0 with $99 \%$ identity, showing high relatedness to phytoplasmas from the neighboring country. The 1,341 bp contain two complete open reading frames (ORFs) whose amino acid sequences have similarity to known phytoplasma proteins. ORF1 from 90 to 509 bp codes a 139-amino-acid protein with similarity to the 50S rp L22, coded by $r p l \mathrm{~V}$. This ORF was very similar to WP017192008 from Poinsettia branch-inducing phytoplasma $(97 \%$ identity, E-value $=1 \mathrm{e}-90,100 \%$ coverage, and score 267), WP053521443 from ' $C a$. P. pruni' (96\% identity, E-value 4e-90, $100 \%$ coverage, and score 266), and WP017192636 from Italian clover phyllody phytoplasma (94\% identity, E-value 6e-80, 93\% coverage, and score 239). ORF2 from 493 to 1,329 bp had similarity to the 30S rp S3, coded by rpsC. Blastp analysis showed it to be similar to WP053521442 from ' $\mathrm{Ca}$. P. pruni' (97\% identity, E-value of 0.0, 100\% coverage, and score 542), WP017192007 from Poinsettia branch-inducing phytoplasma (97\% identity, E-value $0.0,100 \%$ coverage, and score 541), and WP017192637 from Italian clover phyllody phytoplasma (96\% identity, E-value 0.0, $100 \%$ coverage, and score 540). The 1,341-bp sequence obtained also codes for a partial ORF, from nucleotide 1 to 69 , with similarity to $30 \mathrm{~S}$ rp S19, coded by gene rpsS (data not shown). Phylogenetic trees constructed with rp gene sequences also grouped sweet orange phytoplasmas identified in this work with other 16SrIII phytoplasmas (Fig. 2B). PCR amplicons from samples 70571 and 78049 had the same sequence as the plasmid clones obtained from the same samples. Eight additional samples had the rp PCR product partially sequenced, allowing secure 16SrIII phytoplasma identification. Seven of these eight samples were coinfected with ' $\mathrm{Ca}$. L. asiaticus'.

16SrIX HLB phytoplasma in sweet orange. Ten citrus samples positive for the 16SrIX phytoplasma from São Paulo and Minas Gerais States had the 16S rRNA gene amplified and sequenced. The $1,430 \mathrm{bp}$ from the $16 \mathrm{~S}$ rRNA gene sequence for the

TABLE 3. Single nucleotide polymorphisms (SNPs) in both partial 16S ribosomal RNA (rRNA) gene and ribosomal protein (rp) genes rpsSrplVrpsC sequences of the 16SrIII phytoplasmas isolates ${ }^{\mathrm{a}}$

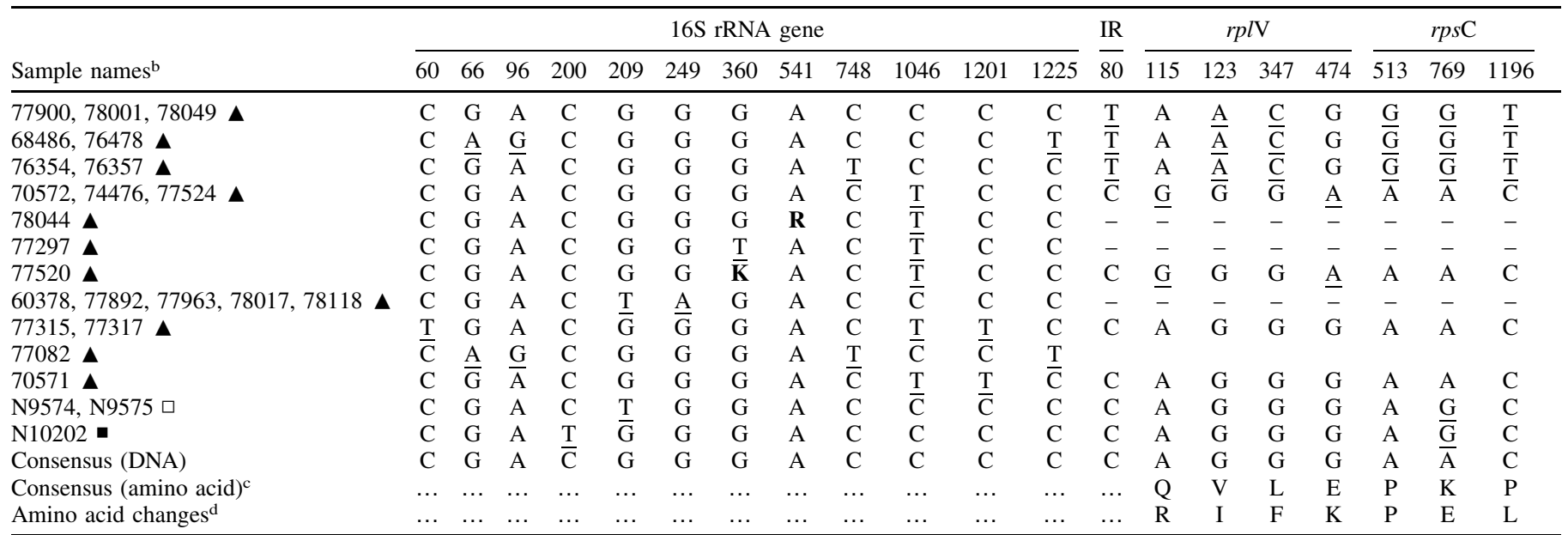

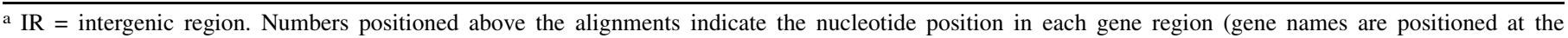
corresponding sequence number from the first SNP). Only SNPs between phytoplasmas from sweet orange are shown, whereas SNPs exclusively from periwinkle and Chinaberry tree phytoplasmas are not shown. SNPs are underlined. Nucleotides in bold are unresolved bases. Standard single-letter codes are used for nucleotide and amino acids. Nucleotide and amino acid consensus represent the most frequent position in the sweet orange phytoplasma sequences.

b Samples from sweet orange $(\boldsymbol{\Delta})$, periwinkle $(\square)$, and Chinaberry tree $(\boldsymbol{\square})$.

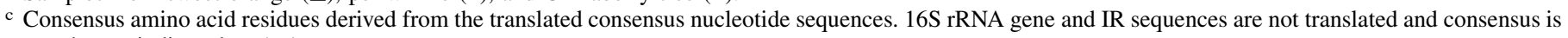
not shown, indicated as (...).

d Amino acids in the corresponding position and changes due to SNPs (underlined nucleotides in the column) are shown. - denotes no sequence obtained. 
16SrIX phytoplasma were $100 \%$ identical among 10 citrus samples (deposited in GenBank with accession numbers MH020223 to MH020232), in contrast to the 16S rRNA gene sequences from the 16SrIII phytoplasma. The consensus sequence was identical to the
16S rRNA gene deposited in GenBank from HLB-associated phytoplasma from sweet orange, 16SrIX group (HQ423159; KM877314), and from the same phytoplasma detected in Sunn Hemp (KF941131) (Wulff et al. 2015). The 16S rRNA gene

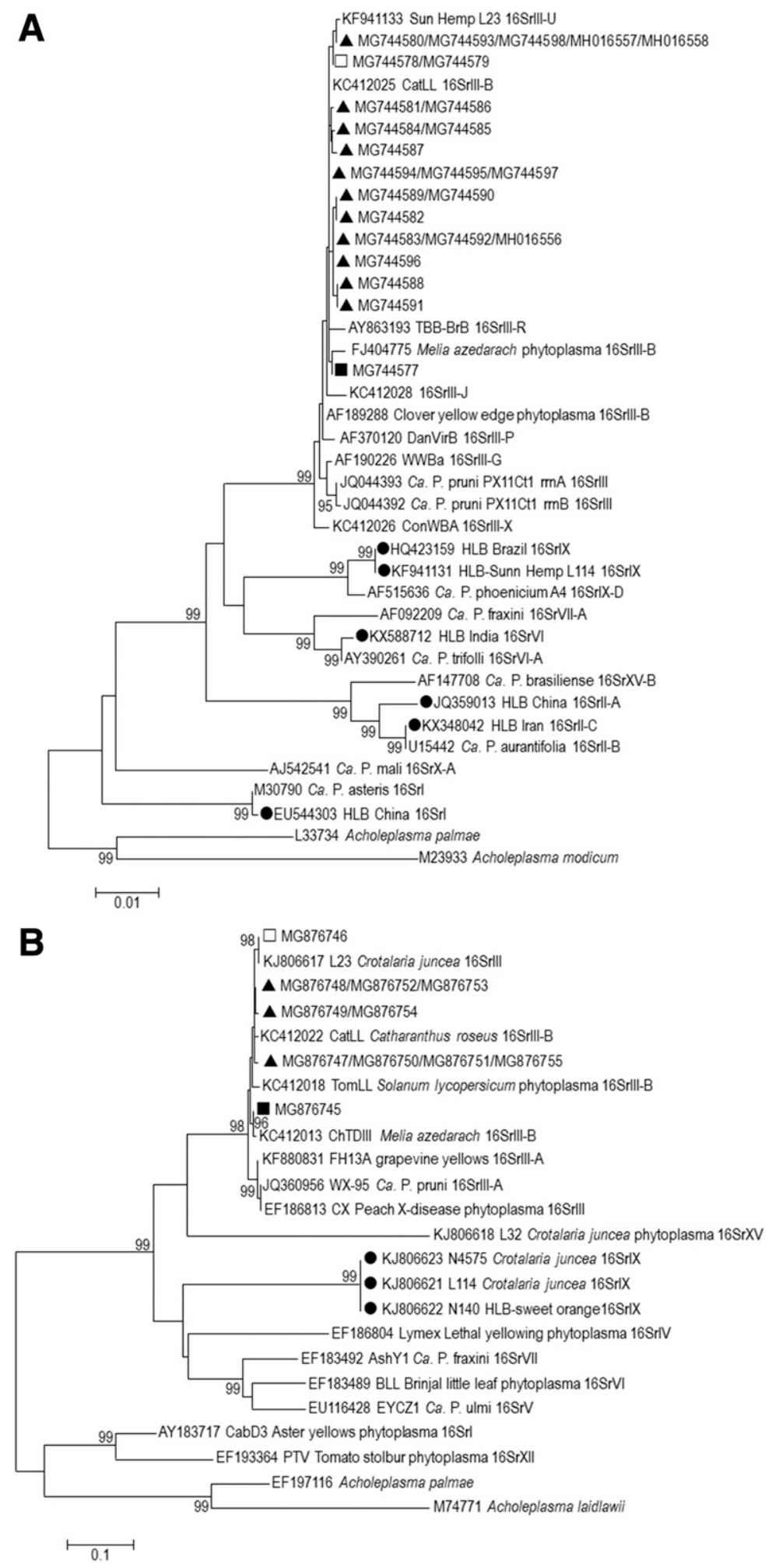

Fig. 2. Phylogenetic trees constructed with A, 16Sr RNA and B, ribosomal protein (rp) gene sequences from representative phytoplasmas and sequences obtained for $16 \mathrm{SrIII}$ phytoplasmas in sweet orange samples in this work. The evolutionary history was inferred using the neighbor-joining method based on 39 nucleotide sequences of the 16Sr RNA gene (A) and of 24 nucleotide sequences of the rp gene sequences (B). Samples from this study are indicated as follows: citrus ( $\mathbf{\Lambda}$ ), periwinkle ( $\square$ ), and chinaberry tree (অ). Accession numbers for the sequences deposited at the National Center for Biotechnology Information are provided. Phytoplasmas from 16Sr groups and huanglongbing phytoplasmas $(\bullet)$ are included for comparison, with indication of group or subgroup and accession number. Evolutionary distances were computed using the maximum composite likelihood method and are in the units of the number of base substitutions per site. Only bootstrap values above 90 are shown on branches. All positions containing gaps and missing data were eliminated and there were a total of 1,178 (A) and 899 (B) positions in the final dataset. Codon positions included were first + second + third + noncoding (only for B). 
sequence was identical (similarity coefficient 1.00) to the reference pattern of 16SrIX group, subgroup A (AF248957).

PCR detection and occurrence of phytoplasmas in HLBaffected citrus. Based on the similarity searches of the two loci, $16 \mathrm{~S}$ rRNA gene and rpsSrplVrpsC genes, a 16SrIII group phytoplasma was found infecting HLB-symptomatic citrus trees. These samples had blotchy mottle or yellowing of the leaves (Fig. $3)$. Although most of the samples were infected with 16SrIII phytoplasma and free of ' $\mathrm{Ca}$. L. asiaticus', ' $\mathrm{Ca}$. L. americanus', and 16SrIX phytoplasmas, coinfection between ' $\mathrm{Ca}$. L. asiaticus' and 16SrIII phytoplasma was observed in nine samples (4\% of samples) (Table 1). PCR with primers rpL2F3 and $\operatorname{rp}(\mathrm{I}) \mathrm{R} 1 \mathrm{~A}$ nested with primers $\mathrm{rp}(\mathrm{III})-\mathrm{FN}$ and $\mathrm{rp}(\mathrm{III}) \mathrm{R} 1$ is a specific detection technique for this phytoplasma (Fig. 1B).

Of the 226 field samples of sweet orange assessed by PCR techniques to detect ' $C a$. L. asiaticus', ' $C a$. L. americanus', $16 \operatorname{SrIX}$ group phytoplasma, and 16SrIII phytoplasma, 59 samples (26.1\%) were positive for the presence of group III phytoplasmas (Table 1). Considering that this survey represents a small portion of the samples analyzed for HLB at Fundecitrus Diagnostic Laboratory, given the total number of samples analyzed from growers, we can say that the incidence of samples infected with 16 SrIII phytoplasma is $0.23 \%$. For the sake of comparison, ' $\mathrm{Ca}$. L. asiaticus' is detected in an average of $75.3 \%$ of samples analyzed at Fundecitrus Diagnostic Laboratory. The 16SrIII phytoplasmas samples came from 10 farms located in seven municipalities: four from São Paulo State (Avaré, Ibaté, Rincão, and Sud Mennucci) and three from Minas Gerais State (Comendador Gomes, Frutal, and Prata).

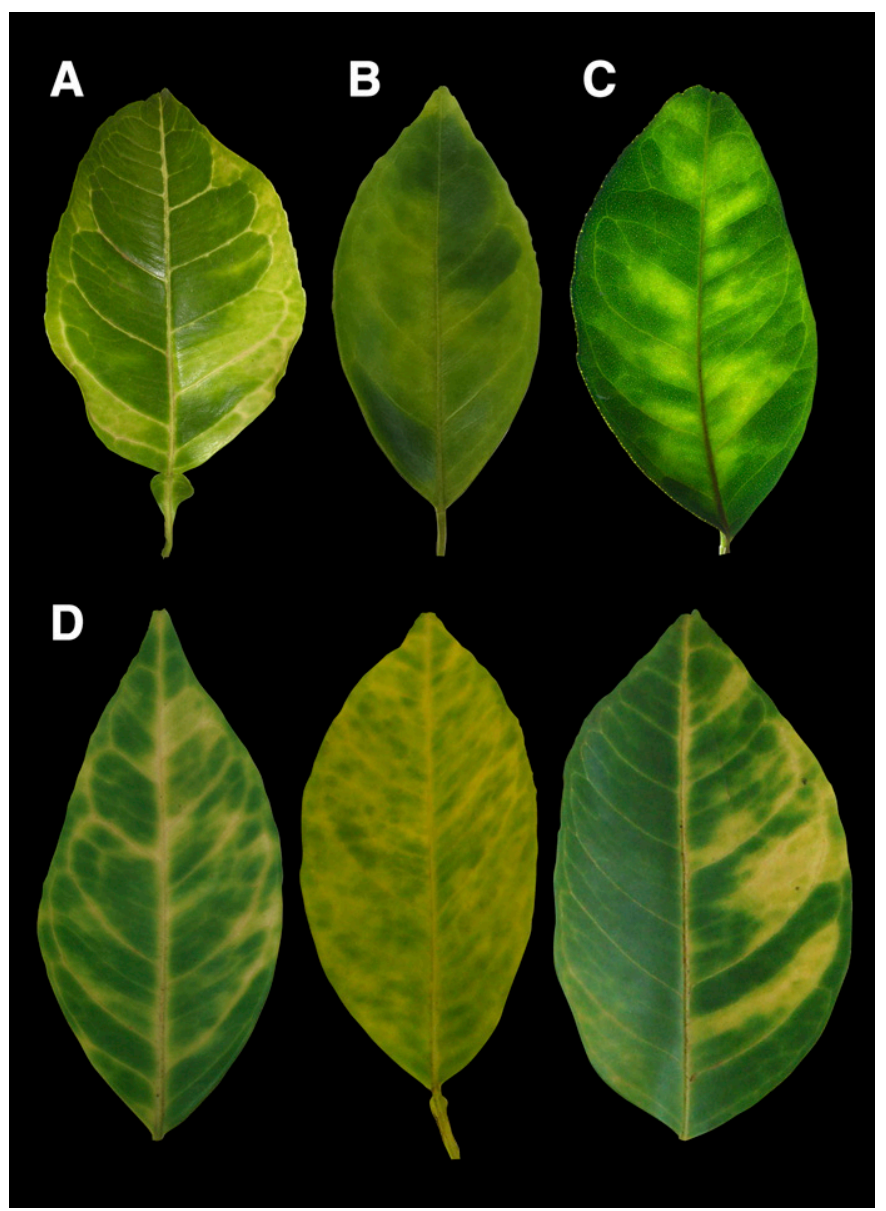

Fig. 3. Blotchy mottle symptoms on sweet orange leaves associated with A, 'Candidatus Liberibacter americanus'; B, 'Ca. L. asiaticus'; and C, 16SrIX phytoplasma and $\mathbf{D}$, three independent samples with blotchy mottle associated with 16 SrIII phytoplasmas.

\section{DISCUSSION}

PCR amplification with universal 16S rRNA gene primers fD1 and rP1 fails to amplify bacterial DNA from blotchy mottled leaves, probably as a reflection of low phytoplasma titer, as observed in the case of the 16SrIX phytoplasma in sweet orange (Teixeira et al. 2008b; Wulff et al. 2015). However, 16SrIII phytoplasma was characterized by phytoplasma-specific PCR amplification from blotchy mottled citrus leaves, free of ' $\mathrm{Ca}$. L. americanus', ' $\mathrm{Ca}$. L. asiaticus', and 16SrIX phytoplasmas in a way similar to that reported for other HLB-associated phytoplasmas, 16SrIX (Teixeira et al. 2008b) and 16SrI (Chen et al. 2009).

A striking characteristic of the group III phytoplasma found infecting sweet orange is the high sequence variants harboring SNPs or haplotypes that we found in the $16 \mathrm{~S}$ rRNA gene and $r p s \mathrm{SrplV} r p s \mathrm{C}$ gene sequences. Although three haplotypes were found for the rps $\mathrm{S} r p l \mathrm{~V} r p s \mathrm{C}$ sequences of 9 samples, at least nine haplotypes were found on the 16S rRNA gene sequences from 22 samples. There is a relation between isolates sharing a given haplotype for rp and $16 \mathrm{~S}$ rRNA genes. The 16SrIII phytoplasmas from sweet orange belong to subgroup 16SrIII-B (15 samples), subgroup 16SrIII-X (2 samples), and a new subgroup most related to 16 SrIII-B (5 samples), with similarity coefficient of 0.94 . However, this potential new subgroup was only characterized by virtual profile of the 16S rRNA gene sequences from five samples and not by PCR-RFLP. Dual infection of dissimilar phytoplasma groups was reported by Harrison et al. (2003) in Chinaberry tree from Colombia. In our case, we found dissimilar subgroups among sweet orange samples but not in the same tree. Liefting et al. (1996) first reported sequence heterogeneity in the two 16S rRNA genes of Phormium yellow leaf phytoplasma (' $\mathrm{Ca}$. P. australiense'), while Davis et al. (2013) reported intragenomic heterogeneity of the $16 \mathrm{~S}$ rRNA gene sequences in ' $\mathrm{Ca}$. P. pruni'. Sequence variations found in some samples seem to be related to differences between rrn operons. Samples 78044 and 77520, despite having several good reads per sample, still remained with a single doubtful nucleotide in each sequence, indicating possible intragenomic variability of the $16 \mathrm{~S}$ rRNA gene regions related to SNPs among other samples (Supplementary Figure S1). Manual curation of such spots confirmed high-quality sequences, in a similar way as reported by Davis et al. (2013).

The high variability observed in $16 \mathrm{~S}$ rRNA gene sequences from group 16SrIII phytoplasmas from citrus was not seen in the sequences from group 16SrIX phytoplasmas, also HLB associated (Teixeira et al. 2008b). Ten $16 \mathrm{~S}$ rRNA gene sequences obtained from 10 samples collected between 2011 to 2016 from six municipalities all had $100 \%$ sequence identity to 16SrIX HLBphytoplasma, indicating no variation in 16S rRNA gene sequences for this citrus phytoplasma. In addition, this confirmed, with a high number of samples, a previous observation that 16SrIX HLBassociated phytoplasma from citrus and from Sunn Hemp are identical, and that Sunn Hemp might be a reservoir plant for phytoplasma spreading by leafhoppers to citrus trees (Marques et al. 2012; Wulff et al. 2015). In the case of 16SrIX phytoplasma, SNPs in the rp gene sequences were found associated with geographic origin and host, with identity of 99.77 to $99.54 \%$ to 16 SrIX HLB phytoplasma from Bahia (Brazil) and Mexico, respectively, and identity of $99.32 \%$ to Gliricidia sepium from Costa Rica (Wulff et al. 2015).

Absence of genetic variability in the $16 \mathrm{~S}$ rRNA gene sequence was also observed for phytoplasma group I collected from maize crops in the São Paulo and Minas Gerais regions (Gomes et al. 2004). Although low variability is expected for this conserved region, the sequence diversity observed for 16SrIII group phytoplasmas in citrus was already observed in this group (Davis et al. 2013; Galdeano et al. 2013; Gundersen et al. 1996). Notably, a higher sequence diversity was observed in the more conserved region (16S rRNA gene) than in more variable regions such as the rp genes in this case. The coexistence of diverse phytoplasma strains in 
the same host species or in the same geographic location can either be interpreted as ongoing evolution of phytoplasmas in adaptation to their geo- and bioecological niches or explained by differences in vector species involvement (Zhao et al. 2010). This diversity may favor genetic recombination and the emergence of new phytoplasmal plant diseases (Zhao et al. 2010).

There is high similarity among South American phytoplasma isolates with the phytoplasmas from sweet orange identified here (Galdeano et al. 2013). 'Ca. P. pruni' is the type member of the $\mathrm{X}$-disease of peach and a high degree of variability is typical in this group (Davis et al. 2013). Phylogenetic trees constructed with 16S rRNA genes and rpsSrplVrpsC sequences position sweet orange isolates among other group 16SrIII phytoplasmas, notably in the subgroups B and X and a potential new subgroup (Fig. 2). According to Davis et al. (2013), these strains could be considered ' $\mathrm{Ca}$. Phytoplasma pruni'-related strains.

The low incidence of group III phytoplasmas in sweet orange is suggestive of an introduction via a polyphagous vector feed from another plant host, likely as in the case of 16SrIX phytoplasmas, also found in low incidence in sweet orange (Marques et al. 2012; Teixeira et al. 2008b; Wulff et al. 2015). A polyphagous insect vectoring these phytoplasmas but not $D$. citri may account for the rare cases of double infection with phytoplasma and ' $\mathrm{Ca}$. L. asiaticus'. Even though the same 16SrIX phytoplasmas was found infecting sweet orange and Sunn Hemp, with $100 \%$ sequence similarity in two loci (Wulff et al. 2015), the 16SrIII phytoplasma in Sunn Hemp (KF941133) (Wulff et al. 2015) is different than the one currently described in sweet orange (subgroups B and X and a potential new subgroup) (Table 2). 16SrIII phytoplasmas are widespread and common in Brazil (Montano et al. 2007) and in the American continent (Davis et al. 2013; Galdeano et al. 2013; Harrison et al. 2003). Also, 16SrI phytoplasmas found in Sunn Hemp (Bianco et al. 2014) are from a different subgroup than the one found in sweet orange in China (Chen et al. 2009) and Mexico (Arratia-Castro et al. 2014). 16SrIX phytoplasma (same haplotype as the HLB-associated phytoplasma) is the most common in Sunn Hemp with witches'-broom in Brazil (Wulff et al. 2015).

Additionally, periwinkle and Chinaberry tree phytoplasma samples were further characterized here. A Chinaberry tree isolate from Rio Grande do Sul State in Brazil belonged to subgroup 16SrIII-B, while the two samples from periwinkle from São Paulo belonged to subgroup $16 \mathrm{SrIII}-\mathrm{B}$, with a similarity coefficient of 0.97 , the limit to a new subgroup (Zhao et al. 2009), being not the same sequences as those found in sweet orange.

Despite the major relevance of ' $\mathrm{Ca}$. L. asiaticus' in relation to the etiology and epidemiological importance in HLB, the current and previous report of phytoplasmas being associated with HLB symptoms, referred to as HLB-associated phytoplasmas, reflect how important it is to better assess the diversity of phloem-limited, insectvectored phytoplasmas in crops such as citrus where, due to the longlasting nature of the crop, trees might remain for decades in the field. The incidence of 16SrIX phytoplasma (Teixeira et al. 2008b) detected with real-time PCR (Wulff et al. 2015) at our laboratory was $0.31 \%$, while the incidence for $16 \mathrm{SrIII}$ phytoplasma reported in the current assessment was $0.23 \%$, considering the total number of samples analyzed for HLB at Fundecitrus Diagnostic Laboratory (more than 27,000 samples between 2012 and 2016). This multitude of phloemrestricted bacteria associated with HLB symptoms indicates a common pathological process incited, although the epidemiological importance of each bacterium is closely associated with its insect vector.

\section{ACKNOWLEDGMENTS}

We thank D. F. Rodrigues, E. A. Souza, J. M. Martins, S. F. Alkimin, and T. M. M. Cardamoni for excellent technical help; V. Duarte from Agronomica for providing an $M$. azedarach-positive sample; $\mathrm{X}$. Foissac for critically reading the manuscript, and V. A. Campos for designing Figure 3.

\section{LITERATURE CITED}

Alizadeh, H., Quaglino, F., Azadvar, M., Kumar, S., Alizadeh, A., Bolboli, F., Casati, P., and Bianco, P. A. 2017. First report of a new citrus decline disease (CDD) in association with double and single infection by 'Candidatus Liberibacter asiaticus' and 'Candidatus Phytoplasma aurantifolia' related strains in Iran. Plant Dis. 101:2145.

Arratia-Castro, A. A., Santos-Cervantes, M. E., Fernández-Herrera, E., Chávez-Medina, J. A., Flores-Zamora, G. L., Camacho-Beltrán, E., Méndez-Lozano, J., and Leyva-López, N. E. 2014. Occurrence of 'Candidatus Phytoplasma asteris' in citrus showing huanglongbing symptoms in Mexico. Crop Prot. 62:144-151.

Barbosa, J. C. 2010. Caracterização molecular e diversidade de fitoplasmas em pomares de citros no estado de São Paulo. Ph.D. thesis, Universidade de São Paulo, Piracicaba, SP, Brazil. http://www.teses.usp.br/teses/disponiveis/ 11/11135/tde-17032011-145314/pt-br.php

Bassanezi, R. B., Montesino, L. H., Gimenes-Fernandes, N., Yamamoto, P. T., Gottwald, T. R., Amorim, L., and Bergamin Filho, A. B. 2013. Efficacy of area-wide inoculum reduction and vector control on temporal progress of huanglongbing in young sweet orange plantings. Plant Dis. 97:789-796.

Belasque, J., Jr., Bassanezi, R. B., Yamamoto, P. T., Ayres, A. J., Tachibana, A., Violante, A. R., Tank, A., Jr., Di Giorgi, F., Tersi, F. E. A., Menezes, G. M., Dragone, J., Jank, R. H., Jr., and Bové, J. M. 2010. Lessons from huanglongbing management in São Paulo State, Brazil. J. Plant Pathol. 92: 285-302.

Bianco, L. F., Martins, E. C., Toloy, R. S., Coletti, D. A. B., Teixeira, D. C., and Wulff, N. A. 2014. First report of phytoplasmas groups 16SrI and 16SrXV in Crotalaria juncea in Brazil. Plant Dis. 98:990.

Bové, J. M. 2006. Huanglongbing: A destructive, newly-emerging, century-old disease of citrus. J. Plant Pathol. 88:7-37.

Bové, J. M., and Garnier, M. 1984. Citrus greening and psylla vectors of the disease in the Arabian Peninsula. Pages 109-114 in: Proc. 9th Conf. IOCV, Riverside, CA.

Capoor, S. P., Rao, D. G., and Viswanath, S. M. 1967. Diaphorina citri: A vector of the greening disease of citrus in India. Indian J. Agric. Sci. 37: 572-576.

Chen, J., Pu, X., Deng, X., Liu, S., Li, H., and Civerolo, E. 2009. A phytoplasma related to 'Candidatus Phytoplasma asteris' detected in citrus showing huanglongbing (yellow shoot disease) symptoms in Guangdong, P. R. China. Phytopathology 99:236-242.

Das, A. K., Nerkar, S., Thakre, N., and Kumar, A. 2016. First report of 'Candidatus Phytoplasma trifolii' (16SrVI group) in Nagpur mandarin (Citrus reticulata) showing huanglongbing symptoms in central India. New Dis. Rep. 34:15.

Davis, R. E., Zhao, Y., Dally, E. L., Jomantiene, R., Lee, I. M., Wei, W., and Kitajima, E. W. 2012. 'Candidatus Phytoplasma sudamericanum', a novel taxon, and strain PassWB-Br4, a new subgroup 16SrIII-V phytoplasma, from diseased passion fruit (Passiflora edulis f. flavicarpa Deg.). Int. J. Syst. Evol. Microbiol. 62:984-989.

Davis, R. E., Zhao, Y., Dally, E. L., Lee, I. M., Jomantiene, R., and Douglas, S. M. 2013. 'Candidatus Phytoplasma pruni', a novel taxon associated with X-disease of stone fruits, Prunus spp.: Multilocus characterization based on 16S rRNA, secY, and ribosomal protein genes. Int. J. Syst. Evol. Microbiol. 63:766-776.

Deng, S., and Hiruki, C. 1991. Amplification of 16S rRNA genes from culturable and non-culturable Mollicutes. J. Microbiol. Methods 14:53-61.

Duan, Y., Zhou, L., Hall, D. G., Li, W., Doddapaneni, H., Lin, H., Liu, L., Vahling, C. M., Gabriel, D. W., Williams, K. P., Dickerman, A., Sun, Y., and Gottwald, T. 2009. Complete genome sequence of citrus huanglongbing bacterium, 'Candidatus Liberibacter asiaticus' obtained through metagenomics. Mol. Plant-Microbe Interact. 22:1011-1020.

FAO. 2016. Citrus Fruit Statistics 2015. Food and Agriculture Organization of the United Nations, Rome.

Galdeano, E., Guzmán, F. A., Fernández, F., and Conci, L. R. 2013. Genetic diversity of $16 \mathrm{SrIII}$ group phytoplasmas in Argentina. Predominance of subgroups 16SrIII-J and B and two new subgroups 16SrIII-W and X. Eur. J. Plant Pathol. 137:753-764.

Garnier, M., Jagoueix, S., Toorawa, P., Grisoni, M., Mallessard, R., Dookun, A., Saumtally, S., Autrey, J. C., and Bové, J. M. 1996. Both huanglongbing (greening) Liberibacter species are present in Mauritius and Reunion. Pages 392-394 in: Proc. 13 ${ }^{\text {th }}$ Conf. IOCV, Riverside, CA.

Gomes, E. A., Jardim, S. N., Guimarães, C. T., Souza, I. R. P., and Oliveira, E. 2004. Genetic variability of Brazilian phytoplasma and spiroplasma isolated from maize plants. Pesqui. Agropecu. Bras. 39:61-65.

Gundersen, D. E., and Lee, I. M. 1996. Ultrasensitive detection of phytoplasmas by nested-PCR assays using two universal primer pairs. Phytopathol. Mediterr. 35:144-151.

Gundersen, D. E., Lee, I.-M., Schaff, D. A., Harrison, N. A., Chang, C. J., Davis, R. E., and Kingsbury, D. T. 1996. Genomic diversity and differentiation among phytoplasma strains in 16S rRNA groups I (aster yellows and 
related phytoplasmas) and III (X-Disease and related phytoplasmas). Int. J. Syst. Bacteriol. 46:64-75.

Harrison, N. A., Boa, E., and Carpio, M. L. 2003. Characterization of phytoplasmas detected in Chinaberry trees with symptoms of leaf yellowing and decline in Bolivia. Plant Pathol. 52:147-157.

Kumar, S., Stecher, G., and Tamura, K. 2016. MEGA7: Molecular Evolutionary Genetics Analysis version 7.0 for bigger datasets. Mol. Biol. Evol. 33:1870-1874

Li, W., Hartung, J. S., and Levy, L. 2006. Quantitative real-time PCR for detection and identification of Candidatus Liberibacter species associated with citrus huanglongbing. J. Microbiol. Methods 66:104-115.

Li, W., Hartung, J. S., and Levy, L. 2007. Evaluation of DNA amplification methods for improved detection of "Candidatus Liberibacter species" associated with citrus huanglongbing. Plant Dis. 91:51-58.

Liefting, L. W., Andersen, M. T., Beever, R. E., Gardner, R. C., and Forster, R. L. S. 1996. Sequence heterogeneity in the two 16S rRNA genes of Phormium yellow leaf phytoplasma. Appl. Environ. Microbiol. 62: 3133-3139.

Lin, H., Pietersen, G., Han, C., Read, D. A., Lou, B., Gupta, G., and Civerolo, E. L. 2015. Complete genome sequence of "Candidatus Liberibacter africanus," a bacterium associated with citrus huanglongbing. Genome Announc. 3:e00733-15.

Lopes, S. A., Bertolini, E., Frare, G. F., Martins, E. C., Wulff, N. A., Teixeira, D. C., Fernandes, N. G., and Cambra, M. 2009. Graft transmission efficiencies and multiplication of 'Candidatus Liberibacter americanus' and ' $\mathrm{Ca}$. Liberibacter asiaticus' in citrus plants. Phytopathology 99:301-306.

Lopes, S. A., Frare, G. F., Camargo, L. E. A., Wulff, N. A., Teixeira, D. C., Bassanezi, R. B., Beattie, G. A. C., and Ayres, A. J. 2010. Liberibacters associated with orange jasmine in Brazil: Incidence in urban areas and relatedness to citrus liberibacters. Plant Pathol. 59:1044-1053.

Lou, B., Bai, X., Bai, Y., Deng, C., Roychowdhury, M., Chen, C., and Song, Y. 2014. Detection and molecular characterization of a 16SrII-A* phytoplasma in grapefruit (Citrus paradisi) with huanglongbing-like symptoms in China. J. Phytopathol. 162:387-395.

Marques, R. N., Teixeira, D. C., Yamamoto, P. T., and Lopes, J. R. S. 2012. Weedy hosts and prevalence of potential leafhopper vectors (Hemiptera: Cicadellidae) of a phytoplasma (16SIX group) associated with huanglongbing symptoms in citrus groves. J. Econ. Entomol. 105:329-337.

Martini, M., Lee, I. M., Bottner, K. D., Zhao, Y., Botti, S., Bertaccini, A., Harrison, N. A., Carraro, L., Marcone, C., Khan, A. J., and Osler, R. 2007. Ribosomal protein gene-based phylogeny for finer differentiation and classification of phytoplasmas. Int. J. Syst. Evol. Microbiol. 57:2037-2051.

Miranda, M. P., dos Santos, F. L., Bassanezi, R. B., Montesino, L. H., Barbosa, J. C., and Sétamou, M. 2018. Monitoring methods for Diaphorina citri Kuwayama (Hemiptera: Liviidae) on citrus groves with different insecticide application programmes. J. Appl. Entomol. 142:89-96.

Montano, H. G., Brioso, P. S. T., and Pimentel, J. P. 2007. List of phytoplasma hosts in Brazil. Bull. Insectol. 60:129-130.

Pietersen, G., Arrebola, E., Breytenbach, J. H. J., Korsten, L., Le Roux, H. F., La Grange, H., Lopes, S. A., Meyer, J. B., Pretorius, M. C., Schwerdtfeger, M., Van Vuuren, S. P., and Yamamoto, P. 2010. A survey for 'Candidatus Liberibacter' species in South Africa confirms the presence of only ' $\mathrm{Ca}$. L. africanus' in commercial citrus. Plant Dis. 94:244-249.

Poghosyan, A., Hernandez-Gonzalez, J., Gallou, A., Andrade-Michel, G., Palacios-Cardiel, C., and Lebsky, V. 2015. First report of 'Candidatus Phytoplasma asteris' in kumquat (Citrus japonica) with HLB-like symptoms in La Paz, Baja California Sur, Mexico. Plant Dis. 99:552.

Roberts, R., Cook, G., Grout, T. G., Khamis, F., Rwomushana, I., Nderitu, P. W., Seguni, Z., Materu, C. L., Steyn, C., Pietersen, G., Ekesi, S., and Roux, H. F. 2017. Resolution of the identity of 'Candidatus Liberibacter' species from huanglongbing-affected citrus in East Africa. Plant Dis. 101:1481-1488.

Saberi, E., Alavi, S. H., Safaie, N., Moslemkhany, C., and Azadvar, M. 2017. Bacterial pathogens associated with citrus huanglongbing-like symptoms in southern Iran. J. Crop. Prot. 6:99-133.

Saglio, P., Lhospital, M., Laflèche, D., Dupont, G., Bové, J. M., Tully, J. G., and Freundt, E. A. 1973. Spiroplasma citri gen. and sp. n.: A mycoplasma- like organism associated with "Stubborn" disease of citrus. Int. J. Syst. Bacteriol. 23:191-204.

Sanches, M. M., Wulff, N. A., Ferreira, E. A., Santos, J. F., Angarten, M. B. O., Carbonari, J. J., Oliveira, R. P., Ishida, A. K. N., and Martins, O. A. 2016. Survey for phytoplasmas and 'Candidatus Liberibacter' sp. from HLB-like symptomatic citrus plants in Brazil. Citrus Res. Technol. 37: 88-93.

Saponari, M., De Bac, G., Breithaupt, J., Loconsole, G., Yokomi, R. K., and Catalano, L. 2010. First report of 'Candidatus Liberibacter asiaticus' associated with huanglongbing in sweet orange in Ethiopia. Plant Dis. 94:482.

Schneider, B., Cousin, M. T., Klinkong, S., and Seemüller, E. 1995. Taxonomic relatedness and phylogenetic positions of phytoplasmas associated with diseases of faba bean, sunhemp, sesame, soybean, and eggplant. Z. Pflanzenkrankh. Pflanzenschutz 102:225-232.

Seemüller, E., Schneider, B., Mäurer, R., Ahrens, U., Daire, X., Kison, H., Lorenz, K. H., Firrao, G., Avinent, L., and Sears, B. B. 1994. Phylogenetic classification of phytopathogenic mollicutes by sequence analyses of $16 \mathrm{~S}$ ribosomal DNA. Int. J. Syst. Bacteriol. 44:440-446.

Teixeira, D. C., Danet, J. L., Eveillard, S., Martins, E. C., Jesus, W. C., Jr., Yamamoto, P. T., Lopes, S. A., Bassanezi, R. B., Ayres, A. J., Saillard, C., and Bové, J. M. 2005. Citrus huanglongbing in São Paulo State, Brazil: PCR detection of the 'Candidatus' Liberibacter species associated with the disease. Mol. Cell. Probes 19:173-179.

Teixeira, D. C., Saillard, C., Couture, C., Martins, E. C., Wulff, N. A., Eveillard-Jagoueix, S., Yamamoto, P. T., Ayres, A. J., and Bové, J. M. 2008a. Distribution and quantification of 'Candidatus Liberibacter americanus', agent of huanglongbing disease of citrus in São Paulo State, Brazil, in leaves of an affected sweet orange tree as determined by PCR. Mol. Cell. Probes 22:139-150.

Teixeira, D. C., Wulff, N. A., Martins, E. C., Kitajima, E. W., Bassanezi, R., Ayres, A. J., Eveillard, S., Saillard, C., and Bové, J. M. 2008b. A phytoplasma closely related to the pigeon pea witches'-broom phytoplasma (16Sr IX) is associated with citrus huanglongbing symptoms in the state of Sao Paulo, Brazil. Phytopathology 98:977-984.

Tyler, H. L., Roesch, L. F. W., Gowda, S., Dawson, W. O., and Triplett, E. W. 2009. Confirmation of the sequence of 'Candidatus Liberibacter asiaticus' and assessment of microbial diversity in huanglongbing-infected citrus phloem using a metagenomic approach. Mol. Plant-Microbe Interact. 22: 1624-1634.

Wang, Z., Yin, Y., Hu, H., Yuan, Q., Peng, G., and Xia, Y. 2006. Development and application of molecular-based diagnosis for 'Candidatus Liberibacter asiaticus', the causal pathogen of citrus huanglongbing. Plant Pathol. 55: 630-638.

Weisburg, W. G., Barns, S. M., Pelletier, D. A., and Lane, D. J. 1991. 16S ribosomal DNA amplification for phylogenetic study. J. Bacteriol. 173: 697-703.

Wulff, N. A., Teixeira, D. C., Martins, E. C., Toloy, R. S., Bianco, L. F., Colletti, D. A. B., Kitajima, E. W., and Bové, J. M. 2015. Sunn hemp, a major sourceplant of the phytoplasma associated with huanglongbing symptoms of sweet orange in São Paulo State, Brazil. J. Citrus Pathol. 2:26956.

Wulff, N. A., Zhang, S., Setubal, J., Almeida, N. F., Martins, E. C., Harakava, R., Kumar, D., Rangel, L. T., Foissac, X., Bové, J. M., and Gabriel, D. W. 2014. The complete genome sequence of 'Candidatus Liberibacter americanus', associated with citrus huanglongbing. Mol. Plant-Microbe Interact. 27:163-176.

Zhao, Y., Wei, W., Davis, R. E., and Lee, I. M. 2010. Recent advances in 16S rRNA gene-based phytoplasma differentiation, classification and taxonomy. Pages 64-92 in: Phytoplasmas: Genomes, Plant Hosts and Vectors. P. G. Weintraub and P. Jones, eds. CABI, Wallingford, UK.

Zhao, Y., Wei, W., Lee, I. M., Shao, J., Suo, X., and Davis, R. E. 2009. Construction of an interactive online phytoplasma classification tool, iPhyClassifier, and its application in analysis of the peach X-disease phytoplasma group (16SrIII). Int. J. Syst. Evol. Microbiol. 59:2582-2593.

Zreik, L., Carle, P., Bové, J. M., and Garnier, M. 1995. Characterization of the mycoplasmalike organism associated with witches'-broom disease of lime and proposition of a Candidatus taxon for the organism, "Candidatus Phytoplasma aurantifolia. Int. J. Syst. Bacteriol. 45:449-453. 